\title{
p16 INK4 expression in precursor lesions of squamous cell cervical cancer related to the presence of HPV-DNA
}

\author{
A.E.G. Godoy, J. Mandelli, F.H. Oliveira, S. Calegari, L.B. Moura and E.P. Serafini \\ Departamento de Ciências Biomédicas, Instituto de Biotecnologia, Universidade de Caxias do Sul, \\ Caxias do Sul, RS, Brasil \\ Correspondence to: A.E.G. Godoy, Departamento de Ciências Biomédicas, Instituto de Biotecnologia, \\ Universidade de Caxias do Sul, Rua Francisco Getulio Vargas, 1130, Bloco S, Sala 507, 95070-560 \\ Caxias do Sul, RS, Brasil \\ E-mail: aeggodoy@ucs.br
}

\begin{abstract}
The purpose of the present study was to identify the expression of $\mathrm{p} 16^{\text {INK4 }}$ in cervical cancer precursor lesions by immunohistochemistry and to correlate it with lesion grade and presence of human papillomavirus (HPV) infection. Cervical specimens from 144 women seen consecutively at the gynecology outpatient clinic of our institution from December 2003 to May 2005 were analyzed by cytopathology, histopathology, polymerase chain reaction for HPV-DNA, and p16 INK4 immunostaining. Histologically normal biopsies, HPV-DNA negative by polymerase chain reaction, were used as control. HPV-DNA prevalence, including the control group, was $68.1 \%$ and the prevalence of $\mathrm{p} 16^{\text {INK } 4}$ expression was $55.0 \%$. The percentage of cells stained by $\mathrm{p} 16^{\text {INK }}$ ranged from 10 to $100 \%$, both in the group consisting of cervical intraepithelial neoplasia (CIN) $1 / \mathrm{HPV}$ specimens and in the group of CIN2/CIN3 specimens with $\mathrm{P}$ value of 0.0001 . p16 INK4 expression was $48.3 \%$ in the CIN1/HPV group, as opposed to $94.3 \%$ in the CIN2/CIN3 group $(P=0.001)$, showing a statistically significant difference between the two groups. The quantitative method used here is simple and less subjective than the different semiquantitative methods described in the literature. In view of the different definitions of a p16/NK4-positive case, it is almost impossible to compare the findings reported by different investigators. This study confirms the association between p16/NK4 and CIN2 and CIN3 lesions. Moreover, it shows that some low grade lesions expressed high levels of this protein. This may indicate that such low grade lesions may be predisposed to progress to high grade lesions. This means that $\mathrm{p} 16^{\mathrm{INK} 4}$ may be a strong marker for "neoplastic lesions" induced by HPV and not just an infection marker.
\end{abstract}

Key words: p16 INK4; Cervical cancer; Human papillomavirus; Immunohistochemistry

Received April 13, 2007. Accepted June 13, 2008

\section{Introduction}

Cervical cancer is one of the most frequent neoplasias in the world, including Brazil, and is responsible for the death of thousands of women every year. The invasive phase of cervical cancer is preceded by an intra-epithelial phase (cervical precursor lesion/intraepithelial neoplasia, $\mathrm{CIN}$ ), and not all women who develop these precursor lesions will have invasive carcinoma in the future.

Human papillomavirus (HPV) infection has been considered to be the main cause of CIN and cancer (1-4), as well as one of the most common sexually transmitted diseases in the world (5-7). HPV-DNA has been detected in almost $100 \%$ of pre-neoplastic and neoplastic cervical lesions (8).

The traditional concept regarding the natural history of cervical cancer considers CIN1, CIN2 and CIN3 to be stages of a single progressive disease. This concept has been challenged, since recent studies have shown that in most women with a CIN2 or CIN3 diagnosis, no alterations suggesting CIN1 were detected in previous tests. This may indicate that $\mathrm{CIN} 1$ and $\mathrm{CIN} 2 / \mathrm{CIN} 3$ represent different disease processes, $\mathrm{CIN} 1$ being the morphological manifestation of HPV infection, while CIN2/CIN3 represents, in addition to the morphological manifestation of HPV infection, 
the true pre-malignant lesion of cervical carcinoma $(3,9,10)$.

Although HPV infection is extremely frequent and is implicated as an etiological factor in cervical cancer, little is known about many basic facts concerning natural history, conditions of infection and risk of progression to premalignant and malignant lesions (5). Cell infection by HPV is shown by changes in function or in the expression of host genes, and the detection of these changes may play a major role in the screening and follow-up of infected patients. Different types of HPV have different levels of association with cancer, and these levels presumably reflect the variation in the potency of their respective viral oncoproteins encoded by E6 and E7 viral genes (11). Interaction between these genes and the host leads to cell cycle deregulation as shown by the abnormal expression of proteins associated with the cell cycle, such as Ki-67, cyclin $\mathrm{E}$ and $\mathrm{p} 16^{\mathrm{INK} 4}$ (11).

Protein $\mathrm{p} 16^{\mathrm{INK}}$, the product of the CDKN2A gene, inhibits cyclin-dependent kinase (a tumor suppressor protein). Its function is to slow down the cell cycle by inactivating the cyclin-dependent kinases that phosphorylate the retinoblastoma protein. A few studies have shown that the expression of $\mathrm{p} 16^{I N K 4}$ is markedly influenced by the expression of the retinoblastoma protein. Overexpression of protein $\mathrm{p} 16^{\mathrm{INK}} 4$ has been demonstrated in cervical cancers due to the functional inactivation of retinoblastoma protein by HPV oncoprotein E7 (8,12-18).

\section{Material and Methods}

This retrospective study was approved by the Review Board of our Institution and all patients gave written informed consent.

All patients in this study were included in a large regional study on HPV conducted at the University of Caxias do Sul, called "Determination and Typing of Human Papillomavirus 16 (HPV 16) in the female population of the Northeast region of the State of Rio Grande do Sul". Women seen at the Lower Genital Tract Pathology Service of the Central Outpatient Clinic (UCS) were included in this study, also approved by the Review Board of the Institution. This outpatient clinic is a secondary referral unit for women sent by primary health care units in the region because of some change in the usual cytopathology (Pap smear).

Cervicovaginal secretion was obtained from all patients included in the study and samples were frozen at $-20^{\circ} \mathrm{C}$ in TE buffer for molecular biology studies. Next, according to a flowchart prepared by the outpatient department for Lower Genital Tract Pathology, the patients were submitted to colposcopy and to a guided biopsy when a lesion was identified.

A total of 144 cervical biopsies obtained from the patients between December 2003 and May 2005 were evaluated. Histopathological specimens were reviewed and classified as normal or presenting HPV infection, CIN1, CIN2 and CIN3 according to the morphological criteria described by Richart (19). Histologically normal biopsies, HPV-DNA negative by PCR, were used as the "control group" to test for p16 INK4 expression. Flat lesions with strictly defined koilocytic atypia and no evidence of proliferation were considered to represent HPV infection. Mild nuclear atypia with minimal proliferation was graded as CIN1. Moderate atypia and proliferation (2/3 of the epithelium) was graded as CIN2 and severe nuclear atypia with intense proliferation (full thickness of the epithelium) was graded as CIN3. Invasive squamous carcinomas and glandular lesions were excluded. The material was submitted to immunohistochemical study for $\mathrm{p} 16^{\text {INK } 4}$ expression using the Cintec p16 ${ }^{I N K 4}$ kit (Dako, clone E6H4, EnVision system, Denmark), according to manufacturer instructions.

The cervicovaginal samples were submitted to a generic PCR to identify HPV-DNA using PGMY 09/11(HPV) and $\mathrm{GH} 20 / \mathrm{PCO} 4$ (for human ß-globin) primers (20).

The evaluation of $\mathrm{p} 16^{\text {NKK4 }}$ expression by immunohistochemistry was performed using a quantitative method with evaluation of percent stained neoplastic cells compared to the total number of neoplastic cells in the lesion. Cells with both cytoplasmic and nuclear staining were considered to be positive. Four microphotographs of the 4 best large magnification fields (400X) were taken with a light microscope and printed on paper. Each photograph was divided into 4 quadrants, and a manual cell count was performed in order to obtain the percentage.

The data were analyzed and processed by SPSS, version 12.0, using non-parametric tests (Tukey and Kruskal-Wallis)

\section{Results}

All 144 cases showed amplification of the human ßglobin gene (100\%), confirming the adequacy of the specimen regarding the quantity and integrity of the genetic material.

As to HPV-DNA, including the control group, the frequency of the virus was $68.1 \%$ (98 cases), while $31.9 \%$ (46 cases) did not present amplification of the $450 \mathrm{bp}$ of gene L1, which produces several different types of genital HPV. None of the samples in the control group tested positive for HPV and therefore they were excluded from Table 1 and Figure 1.

Table 1 shows the distribution of the presence of HPV- 
DNA related to the histopathological diagnosis in the group with histopathological lesions ( $N=115)$, in absolute numbers and as percentage, excluding the control group.

In the 29 cases constituting the control group (classified as histopathologically normal), staining for $\mathrm{p} 16^{\text {NNK4 }}$ was negative both in normal epithelium and stroma, and in the metaplastic and inflammatory cells.

Figure 1 shows case distribution according to the percentage of stained cells. Analysis of this figure shows that the number of cells stained by $\mathrm{p} 16^{I N K 4}$ tended to increase in proportion to the severity of the lesion. At one extreme it can be seen that the lesions caused by HPV infection, in which the expression of p16/NK4 was negative or only weakly positive (with indices of up to $25 \%$ of stained cells), occurred in $80 \%$ of the cases. In contrast, in CIN3 lesions the expression of p16 INK4 was strongly positive (with more than $75 \%$ of cells being stained) in $82 \%$ of the cases.

This means that there was a significant relationship between the increase in the histological grade of the lesion and the number of cells that express $\mathrm{p} 16^{\text {INK4 }}(\mathrm{P}=$ 0.001). However, no statistically significant difference was found between CIN1 and HPV $(P=0.650)$ or between CIN2 and CIN3 $(P=0.789)$.

Figure 1 also reveals that the HPV/ CIN1 group showed a large number of negative cases $(\mathrm{N}=21)$, and that $60 \%$ of the cases considered positive had less than $50 \%$ of stained cells. However, in another $40 \%$ of the HPV/CIN1 cases that expressed p16 ${ }^{\text {INK4 }}$, we found a strong expression of this protein, a few samples having $100 \%$ of stained cells, as observed in high grade lesions.

The opposite occurred when we analyzed the CIN2/CIN3 group, in which there were very few cases $(N=6)$ negative for p16 $1{ }^{\text {NKK } 4}$ or with less than $50 \%$ of stained cells $(11.3 \%$ of the CIN2/CIN3 cases). This means that $88.6 \%$ of the cases of CIN2/ CIN3 were positive for $\mathrm{p} 16^{\text {NKK4 }}$ with more than $50 \%$ of stained cells $(\mathrm{N}=45)$. Among these, a large number of cases revealed $100 \%$ of cells expressing p16 1 NK4 , again confirming the close relationship between the expression of this protein and lesion grade.

In order to determine how closely the expression of $\mathrm{p} 16^{I N K 4}$ in precursor lesions is associated with the presence of HPV-
DNA, the positivity of this protein was correlated with the PCR results for HPV-DNA. The results are summarized in Table 2.

Table 2 shows that $45(72.6 \%)$ of the 62 cases diagnosed as HPV/CIN1 were positive for HPV-DNA. In the 17 remaining cases $(27.4 \%)$ HPV-DNA could not be identified. Twelve $(70.5 \%)$ of these 17 cases negative for HPVDNA also presented negative immunohistochemistry for p16 INK4 , while $5(29.4 \%)$ showed positivity for $\mathrm{p} 16^{I N K 4}$ expression. Interestingly, $4(80 \%)$ of these 5 cases presented weak positivity for the protein, with less than $49 \%$ of the cells stained. Only a single case $(20 \%)$ was strongly positive for $\mathrm{p} 16^{\mathrm{INK}}$, with $65 \%$ of stained cells.

PCR detected HPV-DNA in 51 cases $(96.2 \%)$ in the CIN2/CIN3 ( $N=53)$ group. p16 INK4 staining of the few HPVnegative CIN2/CIN3 cases was either negative or weak, in

Table 1. Distribution of the presence of HPV-DNA related to the histopathological diagnosis $(\mathrm{N}=115)$.

\begin{tabular}{ccccc}
\hline & HPV & CIN1 & CIN2 & CIN3 \\
\hline HPV-DNA (+) & $29(72.5 \%)$ & $16(72.7 \%)$ & $14(93.3 \%)$ & $\begin{array}{c}37(97.3 \%) \\
\text { HPV-DNA (-) }\end{array}$ \\
$11(27.5 \%)$ & $6(27.3 \%)$ & $1(6.7 \%)$ & $1(2.7 \%)$ \\
\hline
\end{tabular}

Data are reported as number of cases with percent in parentheses. HPV = human papillomavirus; $\mathrm{CIN}=$ cervical intraepithelial neoplasia. $\mathrm{CIN} 1=$ mild nuclear atypia with minimal proliferation; CIN2 = moderate atypia and proliferation $(2 / 3$ of the epithelium); CIN3 = severe nuclear atypia with intense proliferation (full thickness of the epithelium).

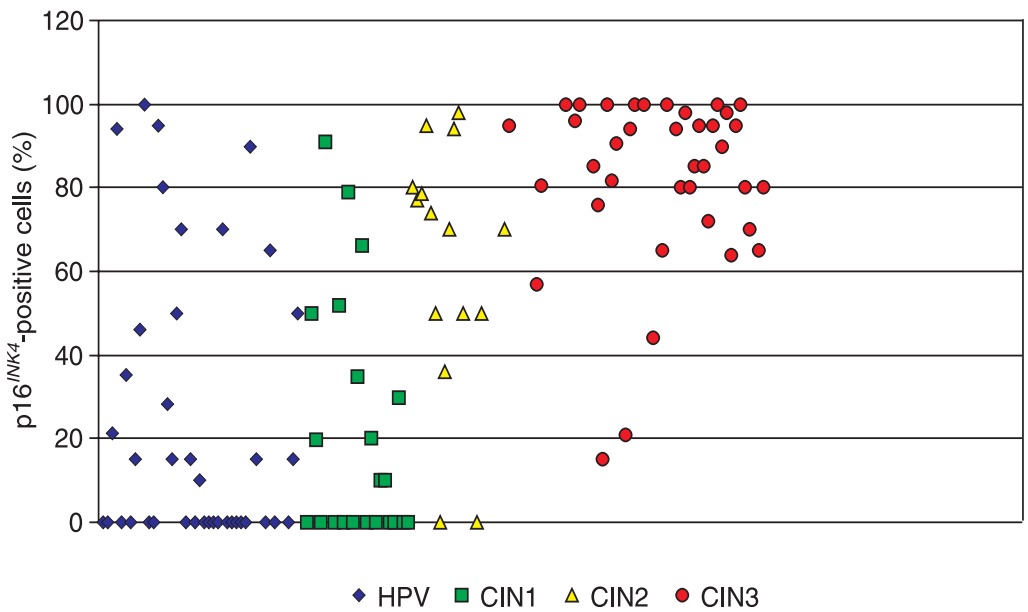

Figure 1. Case distribution according to the percentage of cells positive for p16 ${ }^{I N K 4}$, correlated with lesion grade. Cases $(N=115$, controls excluded) were clustered according to histological diagnosis as $\mathrm{HPV}(\mathrm{N}=40), \mathrm{CIN} 1(\mathrm{~N}=22), \mathrm{CIN} 2$ $(\mathrm{N}=15)$, and CIN3 $(\mathrm{N}=38)$. HPV/CIN1 $\times$ CIN2/CIN3 $(P=0.001), \mathrm{HPV} \times \mathrm{CIN} 1(\mathrm{P}$ $=0.650)$, and CIN2 $\times$ CIN3 $(P=0.789$; Pearson test $)$. HPV = human papillomavirus; $\mathrm{CIN}=$ cervical intraepithelial neoplasia. 
Table 2. p16 INK4 expression in precursor cervical cancer lesions correlated with histopathological diagnosis (Richart) and PCR results for HPV-DNA (absolute number of cases).

\begin{tabular}{|c|c|c|c|c|c|c|}
\hline \multirow[t]{2}{*}{ Total $(N=144)$} & \multicolumn{3}{|c|}{ DNA-HPV (-) $(\mathrm{N}=48)$} & \multicolumn{3}{|c|}{ DNA-HPV $(+)(\mathrm{N}=96)$} \\
\hline & p16 (-) & $\begin{array}{l}\text { p16 (+) } \\
(<49 \%)\end{array}$ & $\begin{array}{l}\text { p16 (+) } \\
(>50 \%)\end{array}$ & p16 (-) & $\begin{array}{l}\text { p16 (+) } \\
(<49 \%)\end{array}$ & $\begin{array}{l}\text { p16 (+) } \\
(>50 \%)\end{array}$ \\
\hline Normal $(\mathrm{N}=29)$ & 29 & 0 & 0 & 0 & 0 & 0 \\
\hline $\operatorname{HPV}(\mathrm{N}=40)$ & 9 & 1 & 1 & 12 & 8 & 9 \\
\hline CIN1 (N = 22) & 3 & 3 & 0 & 7 & 4 & 5 \\
\hline CIN2 (N = 15) & 1 & 0 & 0 & 1 & 2 & 11 \\
\hline CIN3 (N = 38) & 0 & 0 & 1 & 0 & 2 & 35 \\
\hline
\end{tabular}

The expression of $\mathrm{p} 16^{I N K 4}$ was divided in $<49 \%$ and $>50 \%$ according with percentage of cells expressing $\mathrm{p} 16^{I N K 4}$. HPV $=$ human papillomavirus; $\mathrm{CIN}=$ cervical intraepithelial neoplasia. CIN1 = mild nuclear atypia with minimal proliferation; CIN2 = moderate atypia and proliferation (2/3 of the epithelium); CIN3 = severe nuclear atypia with intense proliferation (full thickness of the epithelium).

contrast to the majority of HPV-positive cases in which strong expression of this protein was consistently observed.

\section{Discussion}

HPV-DNA prevalence when molecular biology techniques are used, as in the case of PCR, varies according to the degree of change in the lesion, ranging from $15 \%$ of women who do not present any evidence of a lesion at cytopathological screening and in histopathological tests (21) to $99.7 \%$ in patients with cervical intraepithelial neoplasia (4).

The percentage of HPV-DNA detected in the present study $(68.1 \%)$ corroborates the findings obtained by Cavalcanti et al. (22) in a study conducted in Rio de Janeiro, in which 514 women were asymptomatic or had precursor lesions, with a positive result for HPV-DNA being obtained in $66.7 \%$ of the isolated samples.

In the present study, excluding the control group, which consisted of 29 samples, all of them with a negative PCR for HPV-DNA, the virus frequency in patients with a lesion increased to $83.4 \%$ (98/115 cases). These results agree with Muñoz et al. (23) who detected a higher prevalence of HPV in women living in countries with high rates of cervical cancer (Brazil and Colombia) than in countries with low rates (Spain).

Kulmala et al. (24) showed much lower percentages in a study performed in the Soviet Union, in which the prevalence of HPV-DNA increased in proportion to lesion severity, reaching $91.7 \%$ in patients with CIN3. On the other hand, Lin et al. (25) reported a $53.0 \%$ prevalence of HPVDNA in several different precursor lesions. The data re- ported by Kulmala et al. (24) have a parallel related to the presence of HPV-DNA in the present study in which, considering the cases of CIN2/CIN3 alone, the prevalence of HPV-DNA was $96.2 \%$ (51/53) while the prevalence was $72.4 \%(45 / 62)$ if we consider only the HPV/CIN1 cases.

Kulmala et al. (24) reported results significantly different from those obtained in the present study, with close to $20 \%$ failure to detect HPV-DNA in the CIN2 and CIN3 cases. Certainly, the small number of viral genome copies and the low quality of the samples involved must have played an important part in these results (24). In the present study, the number of precursor lesions that were negative for HPV-DNA in PCR may be due to two main reasons: that these cases are truly negative for viral DNA or that in some of these cases the protocol used was not able to detect viral DNA. The latter statement tends to be true, since some specimens were stored for a few months or years, and it is known that storage time influences the quality of the DNA extracted.

However, these false-negative results tend to be a real clinical problem if, in the future, molecular methods for the detection of HPV-DNA are used singly as a screening method

Despite the small number of cases that proved negative for HPV-DNA by PCR, these results show that PCR should not be used as a single method for patient diagnosis or follow-up, since in about $25 \%$ of the cases it was impossible to identify HPV-DNA, and in $11.2 \%$ (7/62) of this group, $\mathrm{p} 16^{I N K 4}$ expression was positive, showing that cell change had already occurred, although the viral DNA could not be isolated.

The quantitative method used here is simple and less subjective than the different semiquantitative methods described in the literature. In view of the different definitions of a p16 INK4-positive case, it is almost impossible to compare the findings reported by different investigators. Some authors consider a case to be positive when both the cytoplasm and the nucleus are stained, while others consider a case to be positive case when only the nucleus or only the cytoplasm is stained $(8,11,13,24-26)$. The cut-off point for positivity ranges from 10 to $60 \%$ in the literature $(8,11,13,24-26)$.

The present findings show that $\mathrm{p} 16^{\text {INK4 }}$ expression and the number of positive cells tend to increase proportionally with the severity of the lesion. There was a clear distinction between the $\mathrm{p} 16^{I N K 4}$ expression pattern in the group of 
HPV/CIN1 lesions and in the group of CIN2/CIN3 lesions with both methods used. A close correlation was found between the large number of positive cells in the CIN2/ CIN3 group and that described by Branca et al. (26) in a series of $152 \mathrm{CIN}$ in Italy, and by Kalof et al. (27) in a series of 44 cases of CIN in the United States. However, there was no statistically significant difference between the cases classified as HPV/CIN1 or between CIN2 and CIN3. This agrees with the idea that these are two different diseases resulting from HPV infection, the former being HPV/CIN1, the infectious disease, and the latter being CIN2/CIN3, the proliferative (neoplastic) disease (9).

In contrast to the present findings, Klaes et al. (28) detected high positivity for p16/NK4 in $100 \%$ of the cases diagnosed as CIN1 with negative HPV-DNA ( $N=17)$, although these investigators used a semiquantitative method to evaluate the expression of $\mathrm{p} 16^{I N K 4}$. In this study, a few cases of CIN1 had over $60 \%$ of cells stained for $\mathrm{p} 16^{\text {INK4 }}$. What does this mean for women whose specimens have reached high percentages of cells showing $\mathrm{p} 16^{\text {INK } 4}$ expression? Does this finding represent only a relationship between the expression of protein $\mathrm{p} 16^{\text {INK4 }}$ and the virus or a particular HPV type? In our results, we did not find an association of $\mathrm{p} 16^{\text {INK4 }}$ expression and HPV type. Does this indicate that even with lesions that are morphologically characteristic of CIN1/HPV, regardless of HPV type, these patients already present molecular changes that would make their evolutive biological behavior similar to that of a

\section{CIN2/CIN3 case?}

The results obtained for $\mathrm{p} 16^{/ N K 4}$ in CIN2 and CIN3 in the present study proved to be better than those obtained by the Klaes group (28), which reported $75 \%$ positivity for HPV-DNA and $100 \%$ positivity for $\mathrm{p} 16^{\text {INK4 }}$ in CIN2 and CIN3, with $\mathrm{N}=92$.

Although our results show a close association between the high number of cells stained by $\mathrm{p} 16^{\text {INK4 }}$ in CIN2 and CIN3 lesions, no statistically significant difference in pattern of expression was found between CIN2 and CIN3.

Our findings show that the association between PCR and immunohistochemistry may be very useful to help in the differential diagnosis of cervical lesions. The simple positivity of $\mathrm{p} 16^{\text {INK4 }}$ in lesions is not enough to discriminate groups, since as many as $69.5 \%$ of the lesions presented some degree of positivity. However, analysis of Figure 1, which shows the percentage of stained cells, shows that most of the CIN2/CIN3 cases presented high percentages (more than 50\%) of stained cells. The opposite occurred in the HPV/CIN1 cases, as only a small number of which presented more than $50 \%$ of stained cells.

The present study does not establish $\mathrm{p} 16^{\text {INK4 }}$ as a marker of tumor progression. However, it shows a strong correlation of p16/NK4 expression with high grade lesions. Follow-up studies are required to determine the biological behavior of the low grade lesions in which more than $50 \%$ of cells were stained for $\mathrm{p} 16^{\text {INK4 }}$.

\section{References}

1. Kjellberg L, Wadell G, Bergman $F$, Isaksson $M$, Angstrom $T$, Dillner J. Regular disappearance of the human papillomavirus genome after conization of cervical dysplasia by carbon dioxide laser. Am J Obstet Gynecol 2000; 183: 1238-1242.

2. van der Graaf $Y$, Molijn A, Doornewaard $H$, Quint W, van Doorn LJ, van den Tweel J. Human papillomavirus and the long-term risk of cervical neoplasia. Am J Epidemiol 2002; 156: 158-164.

3. Bosch FX, Lorincz A, Munoz N, Meijer CJ, Shah KV. The causal relation between human papillomavirus and cervical cancer. J Clin Pathol 2002; 55: 244-265.

4. Walboomers JM, Jacobs MV, Manos MM, Bosch FX, Kummer JA, Shah KV, et al. Human papillomavirus is a necessary cause of invasive cervical cancer worldwide. $J$ Pathol 1999; 189: 12-19.

5. Sedlacek TV. Advances in the diagnosis and treatment of human papillomavirus infections. Clin Obstet Gynecol 1999; 42: $206-220$.

6. Falls RK. Spontaneous resolution rate of grade 1 cervical intraepithelial neoplasia in a private practice population. $A m$ J Obstet Gynecol 1999; 181: 278-282.
7. Ledger WJ, Jeremias J, Witkin SS. Testing for high-risk human papillomavirus types will become a standard of clinical care. Am J Obstet Gynecol 2000; 182: 860-865.

8. Murphy N, Ring M, Killalea AG, Uhlmann V, O'Donovan M, Mulcahy $F$, et al. p16INK4A as a marker for cervical dyskaryosis: CIN and cGIN in cervical biopsies and ThinPrep smears. J Clin Pathol 2003; 56: 56-63.

9. Schiffman $\mathrm{MH}$. New epidemiology of human papillomavirus infection and cervical neoplasia. J Natl Cancer Inst 1995; 87: 1345-1347.

10. Wright TC, Kurman RJ, Ferenczy A. Precancerous lesions of the cervix. In: Kurman RJ (Editor), Blaustein's pathology of female genital tract. 4th edn. New York, Springer-Verlag; 1994. p 229-278.

11. Keating JT, Cviko A, Riethdorf S, Riethdorf L, Quade BJ, Sun D, et al. Ki-67, cyclin E, and p16INK4 are complementary surrogate biomarkers for human papilloma virus-related cervical neoplasia. Am J Surg Pathol 2001; 25: 884891.

12. Sherr CJ. Cancer cell cycles. Science 1996; 274: 16721677. 
13. Sano T, Oyama T, Kashiwabara K, Fukuda T, Nakajima T. Expression status of $\mathrm{p} 16$ protein is associated with human papillomavirus oncogenic potential in cervical and genital lesions. Am J Pathol 1998; 153: 1741-1748.

14. Huschtscha LI, Reddel RR. p16(INK4a) and the control of cellular proliferative life span. Carcinogenesis 1999; 20: 921-926.

15. Giarre M, Caldeira S, Malanchi I, Ciccolini F, Leao MJ, Tommasino M. Induction of $\mathrm{pRb}$ degradation by the human papillomavirus type $16 \mathrm{E} 7$ protein is essential to efficiently overcome p16INK4a-imposed G1 cell cycle arrest. J Virol 2001; 75: 4705-4712

16. Agoff SN, Lin P, Morihara J, Mao C, Kiviat NB, Koutsky LA. p16(INK4a) expression correlates with degree of cervical neoplasia: a comparison with $\mathrm{Ki}-67$ expression and detection of high-risk HPV types. Mod Pathol 2003; 16: 665-673.

17. Wieland $U$, Pfister $\mathrm{H}$. Infecção por papilomavírus em patologia humana: epidemiologia, patogênese e papel oncogênico. In: Gross GE, Barrasso R (Editors), Papilomavírus humano - atlas clínico de HPV. 1st edn. Porto Alegre: ArtMed; 1999.

18. Kubo A, Nakagawa K, Varma RK, Conrad NK, Cheng JQ, Lee WC, et al. The p16 status of tumor cell lines identifies small molecule inhibitors specific for cyclin-dependent kinase 4. Clin Cancer Res 1999; 5: 4279-4286.

19. Richart RM. A modified terminology for cervical intraepithelial neoplasia. Obstet Gynecol 1990; 75: 131-133.

20. Gravitt PE, Peyton CL, Alessi TQ, Wheeler CM, Coutlee F, Hildesheim A, et al. Improved amplification of genital human papillomaviruses. J Clin Microbiol 2000; 38: 357-361.

21. Nonnenmacher B, Breitenbach V, Villa LL, Prolla JC,
Bozzetti MC. Genital human papillomavirus infection identification by molecular biology among asymptomatic women. Rev Saúde Pública 2002; 36: 95-100.

22. Cavalcanti SM, Zardo LG, Passos MR, Oliveira LH. Epidemiological aspects of human papillomavirus infection and cervical cancer in Brazil. J Infect 2000; 40: 80-87.

23. Muñoz N, Kato I, Bosch FX, Eluf-Neto J, De Sanjose S, Ascunce N, et al. Risk factors for HPV DNA detection in middle-aged women. Sex Transm Dis 1996; 23: 504-510.

24. Kulmala SM, Syrjänen S, Shabalova I, Petrovichev N, Kozachenko V, Podistov J, et al. Human papillomavirus testing with the hybrid capture 2 assay and PCR as screening tools. J Clin Microbiol 2004; 42: 2470-2475.

25. Lin WM, Ashfaq R, Michalopulos EA, Maitra A, Gazdar AF, Muller CY. Molecular Papanicolaou tests in the twenty-first century: molecular analyses with fluid-based Papanicolaou technology. Am J Obstet Gynecol 2000; 183: 39-45.

26. Branca M, Ciotti M, Santini D, di Bonito L, Giorgi C, Benedetto $A$, et al. p16(INK4A) expression is related to grade of cin and high-risk human papillomavirus but does not predict virus clearance after conization or disease outcome. Int $J$ Gynecol Pathol 2004; 23: 354-365.

27. Kalof AN, Evans MF, Simmons-Arnold L, Beatty BG, Cooper K. p16INK4A immunoexpression and HPV in situ hybridization signal patterns: potential markers of high-grade cervical intraepithelial neoplasia. Am J Surg Pathol 2005; 29: 674-679.

28. Klaes R, Friedrich T, Spitkovsky D, Ridder R, Rudy W, Petry $\mathrm{U}$, et al. Overexpression of p16(INK4A) as a specific marker for dysplastic and neoplastic epithelial cells of the cervix uteri. Int J Cancer 2001; 92: 276-284. 